\title{
Climate Variability, Impacts and Adaptation Strategies: The Case of Mbeya and Makete Districts in Great Ruaha Catchment in Tanzania
}

\author{
Shadrack Mwakalila \\ Department of Geography, University of Dar es Salaam, Dar es Salaam, Tanzania \\ Email:smwakalila@yahoo.com
}

Received October 21, 2013; revised November 19, 2013; accepted December 15, 2013

Copyright (C) 2014 Shadrack Mwakalila. This is an open access article distributed under the Creative Commons Attribution License, which permits unrestricted use, distribution, and reproduction in any medium, provided the original work is properly cited. In accordance of the Creative Commons Attribution License all Copyrights (C) 2014 are reserved for SCIRP and the owner of the intellectual property Shadrack Mwakalila. All Copyright (C) 2014 are guarded by law and by SCIRP as a guardian.

\begin{abstract}
This paper presented key findings from the study which aimed to assess the impacts of climate variability and local adaptation strategies in selected villages of Mbeya and Makete Districts located in the most upper Great Ruaha River catchment in Southern Tanzania. Together, the study districts cover a wide range of climate change related hazards. Both qualitative and quantitative methods are used for data collection and analysis. The study shows that, there is significant change in pattern and amount of rainfall contributing to water stress, making people more vulnerable. Local communities are adapting to spatial and temporal climate variability, with varying degrees of success. Traditional smallholder irrigated systems used as adaptation strategies for crop production are characterized by low water use efficiency and high water losses. This implies that, if irrigation is managed properly, it can lead to sustainable increases in small farmer's productivity and income, thus alleviating rural poverty and enhancing environmental management objectives.
\end{abstract}

\section{KEYWORDS}

\section{Climate Variability; Peoples’ Perception; Water Resources; Great Ruaha Catchment}

\section{Introduction}

Climate change is one of the great challenges facing the Great Ruaha River Catchment in Tanzania (Figure 1). The impacts of climate change on freshwater ecosystems can be characterised by shifts in water quality, water quantity, and water timing. Globally, water timing is likely to be the most important impact for both humans and other species since it directly affects both water quantity and quality and because humans and other species often exhibit behaviours that depend on predictable changes in flow.

Since climate change/variability adds the existing water stresses and scarcity, watershed management therefore, is a key component of adaptation [1,2]. In the river basin, management of non-climate and climate change impacts on water are inextricably linked [3]. Water resource adaptation options need to be able to function under uncertain future climate change, but many adapta- tion measures do not sufficiently account for this [4]. The building of dams and large-scale irrigation systems for example cannot completely protect against floods and can also damage the adaptation capacity of other sectors, an example of maladaptation [5]. Technical measures such as desalination, pumping of deep groundwater, and water treatment are very resource intensive [4]. In principle, restoring and protecting freshwater habitats and watersheds and managing natural floodplains are key elements for sustainable adaptation strategy [6]. This paper presented key findings from the study which aimed to assess the impacts of climate variability and local adaptation strategies in selected villages of Mbeya and Makete Districts located in Great Ruaha River catchment in Southern Tanzania.

\section{Methodology}

The study was conducted in Mbeya and Makete Districts, 


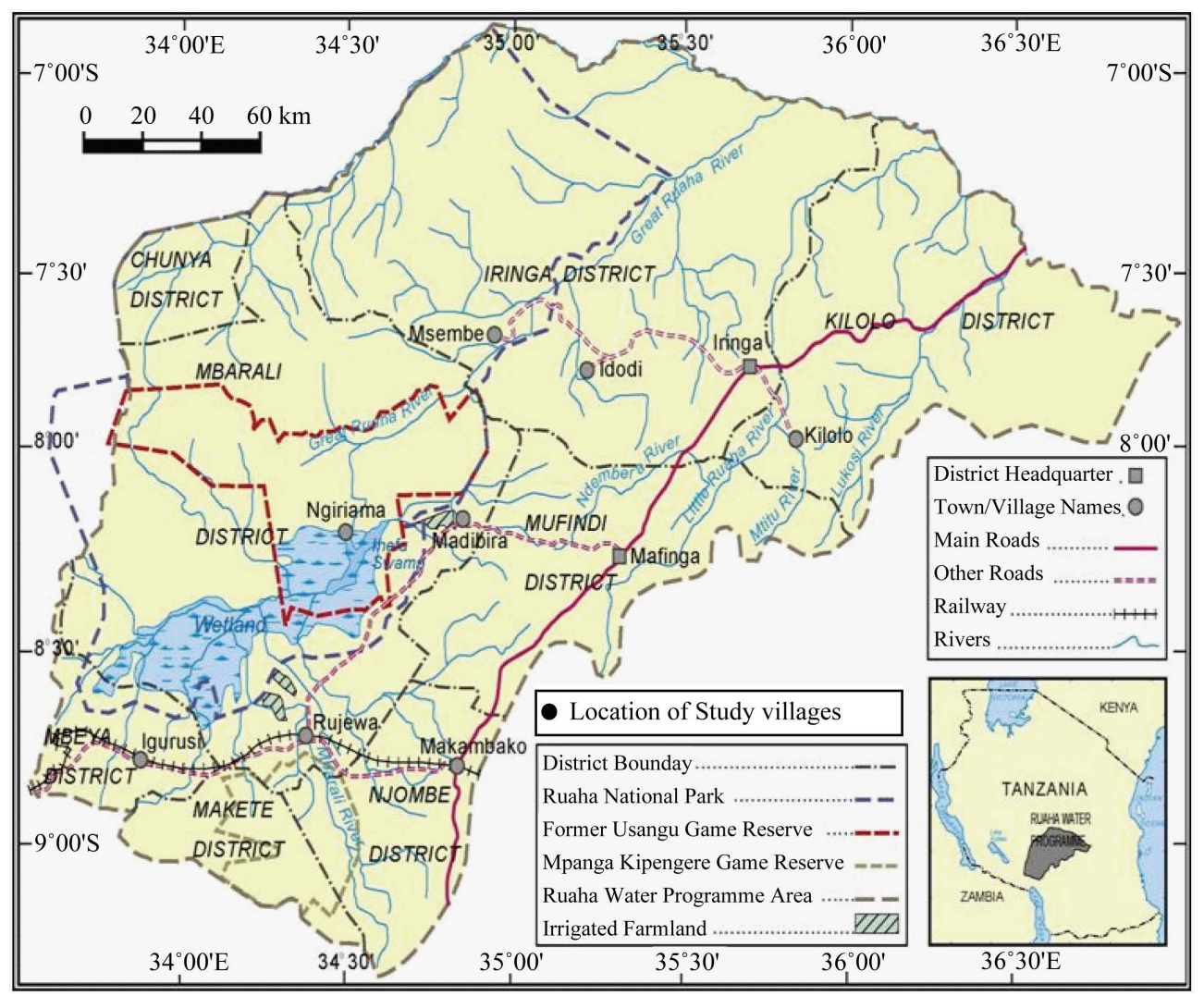

Figure 1. Location of study villages in Great Ruaha River Catchment.

the most upper part of the Great Ruaha River Catchment in Southern Tanzania (Figure 1). The justification of selecting this study area was based on the fact that, first the study districts cover a wide range of climate change related hazards, secondly, the waters of the Ruaha form a crucial input into the livelihoods of communities in the upper catchment as well as the lower catchment. The waters support in rice, maize, vegetable production and livestock keeping. The wildlife habitats of Ruaha National Park and surrounding game reserves are dependent on the Ruaha River for their very survival. The communities in the study area all depend on land, water, resources to live and produce goods.

In order to capture the different community characteristics and extent of vulnerabilities to climate change. From each district three villages were selected purposively. In total six villages were selected as follows: Mbeya District: Itewe, Idunda and Tembela village; Makete District: Matamba, Mpangala and Kimani village. The sample size was determined based on the formula for determining sample size from a finite population [7]. In view of the amount and the details of information required in a limited period of time the methodology was based on Participatory Rural Appraisal (PRA) [8]. Both quantitative and qualitative data analysis methods were used [7]. Quantitative data from household survey were coded and entered into SPSS version 21 software for analysis. The analysis was presented using descriptive statistics such as frequencies and percentage distributions.

\section{Results and Discussion}

\subsection{Climate Variability and Impacts}

The rainfall regime in most of the study area has a single rainy season from November through May, and no rainfall during the rest of the year. In the high rainfall areas the dry season is shorter as the rainy season tends to continue until June. The heaviest rainfall generally occurs in December-January or March-April. The monthly mean rainfall and standard deviation for 2 catchments are presented in Figure 2. The relatively high standard deviation in the transition months is due to variations from year to year of the onset and termination of the rainy season. In addition, the rainfall amount as well as the onset of rainy season can vary considerably from year to year, which often has a detrimental effect for crop production.

As it applies for the rainfall the potential evapotranspiration varies considerably within the study area. However, seasonal variation is smaller and steady for potential evapotranspiration compared to the rainfall as seen in 
Figure 3, which depicts the corresponding mean monthly values of potential evapotranspiration and rainfall. The potential evapotranspiration is lowest during the wet season and increases during the dry season, reaching a maximum at the end of the dry season. Due to high seasonal potential evapotranspiration rates compared to the seasonal rainfall, most of the study villages have an an-

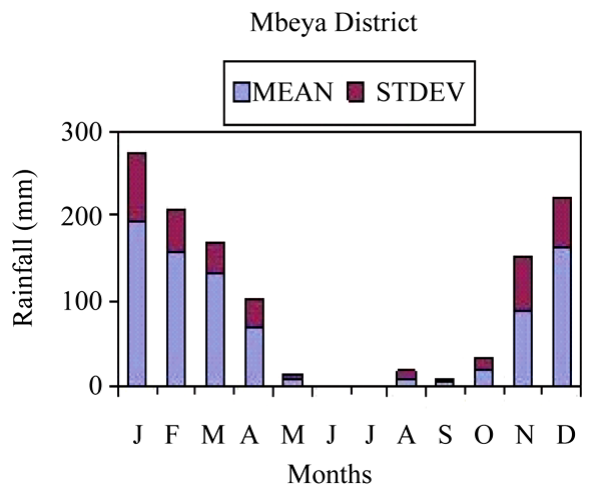

nual rainfall deficit.

Following household survey on climate variability, most respondents confirmed spatial and temporal rainfall variability in their village (Table 1). This variability is associated with: Changes in rainfall pattern and amounts, shortage of water, outbreak of diseases making people more vulnerable.

Figure 2. Monthly mean rainfall in sub-catchments of Great Ruaha River.
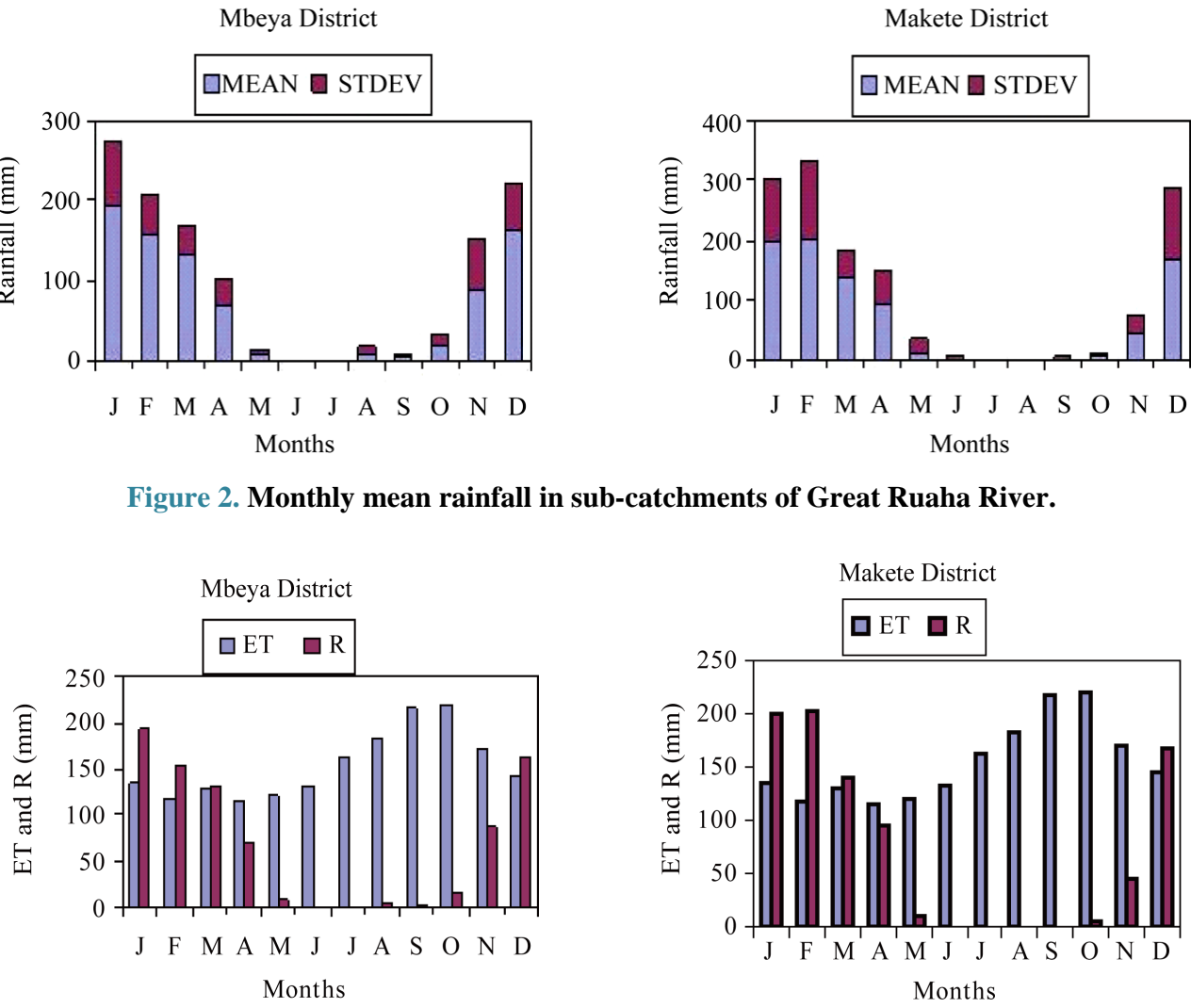

Figure 3. Variations of mean monthly evapo-transpiration (ET) and rainfall (R).

Table 1. (a) Peoples' perception on climate variability in Tembela village-Mbeya; (b). Peoples’ perception on climate variability in Matamba village-Makete.

(a)

\begin{tabular}{ccccc}
\hline Climate variability perception & Frequency & Percent & Valid Percent & Cumulative Percent \\
\hline Changes in rainfall pattern and amounts & 33 & 66.0 & 66.0 & 66.0 \\
Shortage of water & 14 & 28.0 & 28.0 & 94.0 \\
Outbreak of diseases & 3 & 6.0 & 6.0 & 100.0 \\
Total & 50 & 100.0 & 100.0 & \\
\hline
\end{tabular}

(b)

\begin{tabular}{ccccc}
\hline Climate variability perception & Frequency & Percent & Valid Percent & Cumulative Percent \\
\hline Changes in Rain fall pattern and amounts & 25 & 50.0 & 50.0 & 50.0 \\
Shortage of water & 3 & 6.0 & 6.0 & 56.0 \\
Outbreak of Diseases & 3 & 6.0 & 6.0 & 62.0 \\
Variations in Temperature & 16 & 32.0 & 32.0 & 94.0 \\
Others & 3 & 6.0 & 6.0 & 100.0 \\
Total & 50 & 100.0 & 100.0 & \\
\hline
\end{tabular}


Most of respondents in the study villages reported that climate variability affects crop production which leads to food insecurity. For example in Itewe village, the results depict that about $48 \%$ of the respondents said that hunger/famine are the event related to climate variability in the village this followed by $24 \%$ who said drought, $18 \%$ responded that flood is related to climate variability and the least was $10 \%$ who reported that, eruption of diseases is caused by climate variability (Figure 4).

\subsection{Water Related Adaptation Strategies for Agricultural Production}

\subsubsection{Traditional Smallholder Irrigated Agriculture}

Local communities in study villages are practising traditional smallholder irrigated agriculture as adaptation strategy. The primary reason for irrigating land is to improve or sustain agricultural productivity in areas where surface soils are dry. Rainfall in the study area is low and unreliable. This state of climate limits the growth of agricultural crops as well as other human activities relying on water for their growth. Traditional schemes are usually initiated and operated by farmers themselves, with no external intervention or support. Usually locally available materials such as stones, grass, wooden poles and earth are used to build intake structures and aqueducts. The building and maintenance of these systems is labourintensive, with the earth canals dug and cleaned by hand. The systems are found in both the upper catchment (where they are used for dry season cultivation) and in the lower catchment (where they are used for a mix of rainy season paddy cultivation and dry season cultivation). Figure 5 show typical intake structures and Conveyance canals used in traditional irrigation schemes. Intake structures are usually built across the river, partially or wholly blocking the channel, and are thus prone to damage during high river flows. The majority of intakes do not have control gates to regulate the amount of water entering the furrow. Conveyance canals are usually hand dug and not lined to minimize seepage. Because the canals are unlined, they quickly get clogged by vegetation growth which reduces their efficiency. Major vege-

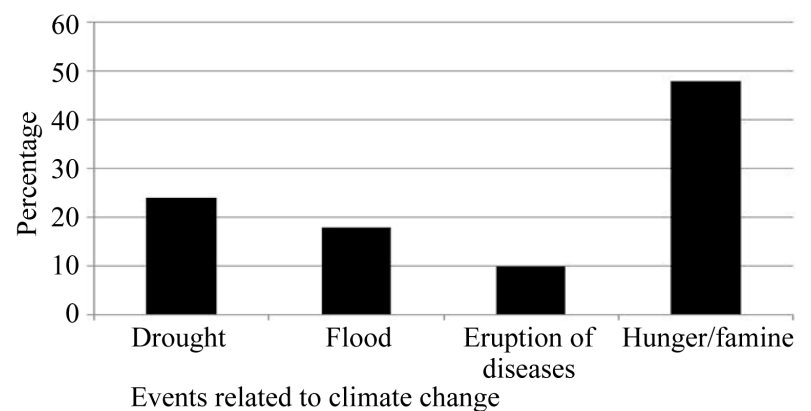

Figure 4. Impact of climate variability.

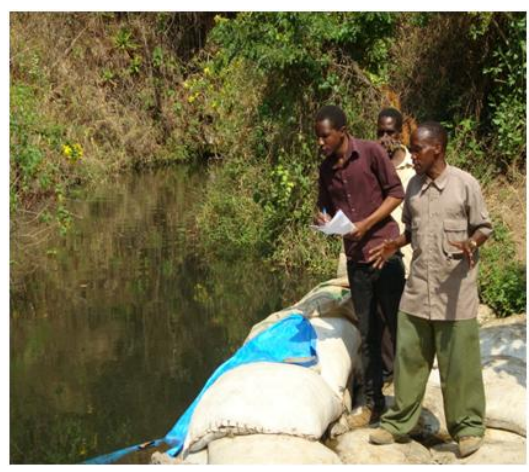

(a)

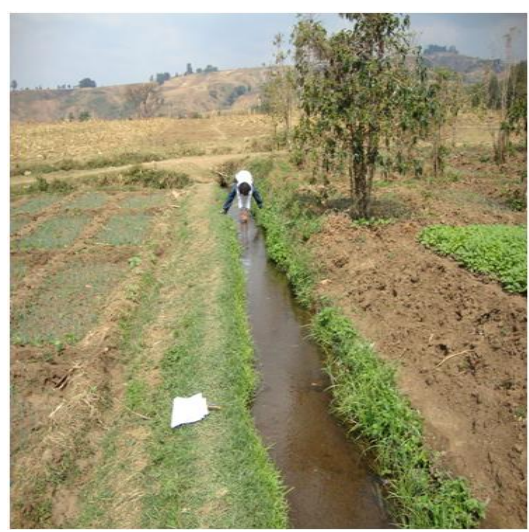

(b)
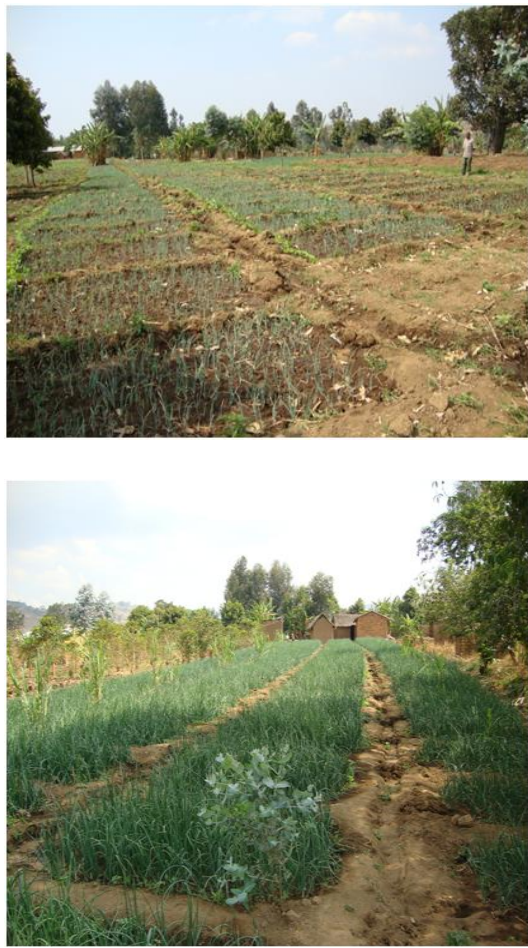

(c)

Figure 5. (a) Traditional water intake for Irrigation and domestic use in Idunda village; (b) Hand dug canal for irrigation and domestic use; (c) Traditional Irrigation farming at Idunda village during the dry season. 
tables grown under irrigation are onions and tomatoes.

\subsubsection{Implementation of Farmers Field Schools}

Field observation noted the Farmers Field Schools (FFS) established by WWF for increasing water use efficiency at field level (Figure 6). The FFS emphasized good management of irrigation water. The FFS have small (usually about $1000 \mathrm{~m}^{2}$ ) field for group study. This is the core of the FFS. This field is essential for FFS because farmers can carry out studies without personal risk allowing them to take management decisions that they might not otherwise attempt in trials on their own farm. This provides farmers a way of testing a new method themselves before applying it to their own fields. It also allows for more interesting research topics such as application of the right amount of irrigation water for high rice productivity. The arrangement for this field varies based on local conditions. Some villages have communal lands that can be used for free, some villages may request on inputs, others areas may request compensation in case of lower yields in experiments, etc.

\subsection{Challenges on Local Adaptation Strategies}

\subsubsection{Cultivation across the Slopes in Water Catchment Areas}

Field observation noted that, cultivation is practised across the slopes in water catchment areas making the cultivated land susceptible to soil erosion and unsustainable water resources availability during the dry season. (see Figure 7). The problem of erosion is only one of many problems such as lack of water, lack of fuelwood, lack of transport and erratic rainfall that are faced by farmers in the study area. Soil erosion by water is a major hazard in Tembela and Matamba villages in Mbeya and Makete districts respectively. The effect of erosion on crop productivity can only be guessed at bet where the land surface has been lowered, due to erosion, crops appear to be less vigorous and show signs of nutrient defi-

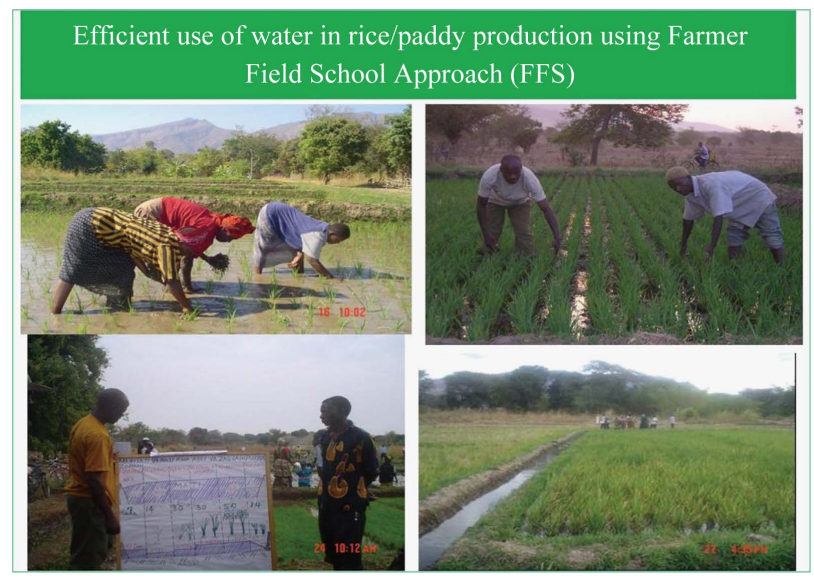

Figure 6. Demonstration of farmers field school.
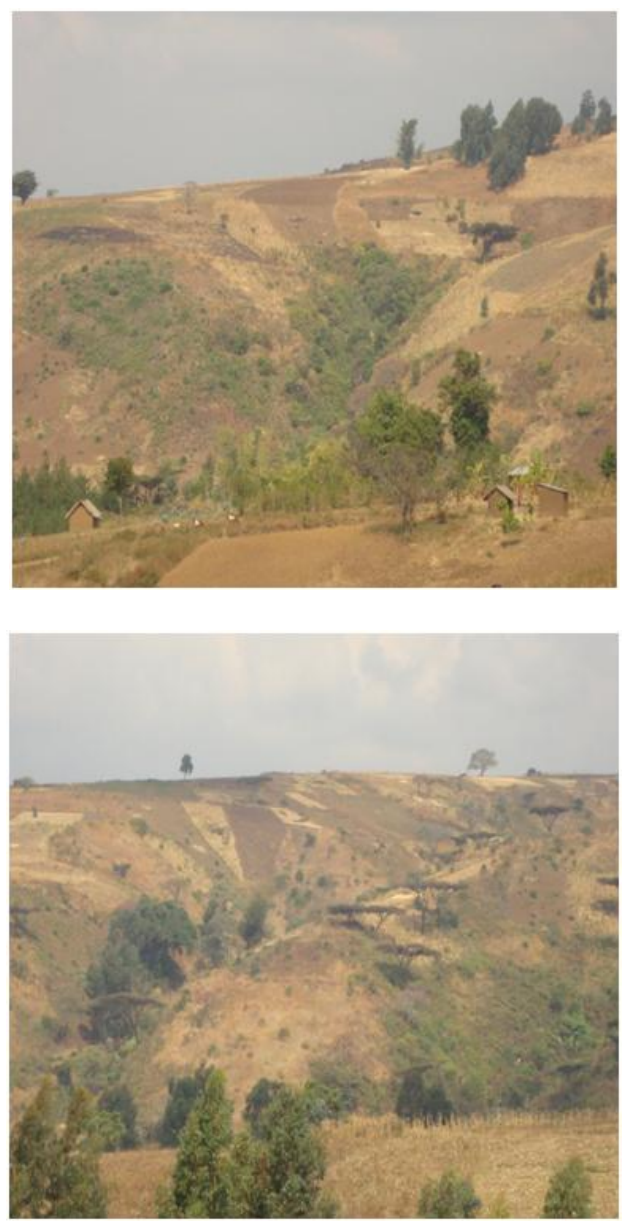

Figure 7. Cultivation on water catchment areas in Tembela village.

ciency. On the steeper slopes the soil profile is shallow, e. g. about $0.5 \mathrm{~m}$ or less, and loss of depth through erosion will inevitably reduce the water-holding capacity. In lowlying areas where deposition occurs, crops can be buried by sediment transported from higher ground.

Although the farmers in the area have little control over rainfall intensity, the effects of raindrop impact and runoff can be controlled through use of proper soil-conservation measures. Conservation on cropland should aim at conserving water and conserving soil at the same time as maintaining or raising fertility and increasing production. Cultural measures which could be useful include measures to speed up the formation of ground cover. Beans give faster protection than maize and are useful in pure stand or where inter-planted. They are also more reliable in an area where maize is prone to fail. Structural measures which will assist conservation include narrow grass strips which are relatively easy to establish once the most suitable grasses have been identified. While trying to reduce runoff it is necessary to identify the natural waterways through which surplus runoff from hillsides can reach the main water courses. 


\subsubsection{Water Management in Traditional Smallholder Irrigation Schemes}

The main water management challenges include unsustainable agricultural practices such as valley bottom cultivation and inefficient irrigation practices particularly in smallholder farms. Traditional irrigation schemes are the majority in Kimani village (Makete) and Idunda village (Mbeya). The amount of water diverted is not controlled because of the absence of the gates. The intakes are subject to frequent damage, often are washed away by floods during rain periods leading to unreliable water supplies and repeated construction of new intake every year. Also there is a possibility of diverting excessive water resulting into floods big enough to cause damage to properties, crops and life it may lead to the river changing its course to follow the dug canal. Water is conveyed to field through traditionally hand dug canals/channel and these are not properly designed and have no definite shapes for good conveyance efficiency. These channels lack control devices for effective conveyance and distribution. These are unlined channels with higher conveyance losses through seepage, evaporation, etc. This has implications for overall irrigation water use since traditional schemes which are characterized by low water use efficiency and high water losses. It also illustrates great potential for water saving if traditional infrastructure is replaced with improved infrastructure.

\section{Conclusion}

Rural communities in study villages face serious climaterelated challenges and have to adapt to spatial and temporal climate variability, with varying degrees of success. Traditional smallholder irrigated schemes used as adaptation strategies are characterized by low water use efficiency and high water losses. The potential implication of the current traditional irrigation systems is that if irrigation is managed properly, it will lead to sustainable increases in small farmer's productivity and income, thus alleviating rural poverty and enhancing environmental management objectives. However, in order to sustain water related adaptation strategies in this area, there is need to enforce the law to better use and protect water sources and management of water demand among users in order to satisfy the need for other users downstream.

\section{Acknowledgements}

The author wish to acknowledge financial support received from the CCIAM Research Programme through the University of Dar es Salaam, Tanzania. The author is grateful for the support and input from village Government Officers in Matamba and Itewe wards.

\section{REFERENCES}

[1] R. Kangalawe, S. Mwakalila and P. Masolwa, "Climate Change Impacts, Local Knowledge and Coping Strategies in the Great Ruaha River Catchment Area, Tanzania,” Natural Resources, Vol. 2, No. 4, 2011, pp. 212-223. http://dx.doi.org/10.4236/nr.2011.24027

[2] B. C. Bates, Z. W. Kundzewicz, S. Wu and J. P. Palutikof, "Climate Change and Water. Technical Paper of the Intergovernmental Panel on Climate Change,” IPCC Secretariat, Geneva, 2008, p. 210.

[3] J. Pittock, C. M. Finlayson, A. Gardner and C. Mckay, "Changing Character: The Ramsar Convention on Wetlands and Climate Change in the Murray-Darling Basin, Australia," Environmental and Planning Law Journal, Vol. 27, No. 1, 2010, pp. 401-425.

[4] V. Krysanova, H. Buiteveld, D. Haase, F. F. Hattermann, K. van Niekerk, K. Roest, P. Martinez-Santos and M. Schluter, "Practices and Lessons Learned in Coping with Climatic Hazards at the River-Basin Scale: Floods and Droughts,” Ecology and Society, Vol. 13, 2008.

[5] C. Fraiture, V. Smakhtin, D. Bossio, P. McCornick, C. Hoanh, A. Noble, D. Molden, F. Gichuki, M. Giordano, M. Finlayson and H. Turral, "Facing Climate Change by Securing Water for Food, Livelihoods and Ecosystems," SAT eJournal, Vol. 4, 2007, pp. 1-21.

[6] V. Galaz, "Water Governance, Resilience and Global Environmental Change: A Reassessment of Integrated Water CO Resources Management (IWRM)," Water Science and Technology, Vol. 56, No. 4, 2007, pp. 1-9. http://dx.doi.org/10.2166/wst.2007.530

[7] C. Kothari, "Research Methodology, Methods and Techniques,” 2nd Edition, VishwaPrakshan, New Delhi, 2004.

[8] T. Joachim and G. Heather, "Participatory Rural Appraisal for Community Development. Training Manual,” International Institute for Environment and Development (IIED), London, 1991. 